University of Chicago Law School

Chicago Unbound

Public Law and Legal Theory Working Papers

Working Papers

2005

\title{
Against Prediction: Sentencing, Policing, and Punishing in an Actuarial Age
}

Bernard E. Harcourt

Follow this and additional works at: https://chicagounbound.uchicago.edu/public_law_and_legal_theory

Part of the Law Commons

Chicago Unbound includes both works in progress and final versions of articles. Please be aware that a more recent version of this article may be available on Chicago Unbound, SSRN or elsewhere.

\section{Recommended Citation}

Bernard E. Harcourt, "Against Prediction: Sentencing, Policing, and Punishing in an Actuarial Age " (University of Chicago Public Law \& Legal Theory Working Paper No. 94, 2005).

This Working Paper is brought to you for free and open access by the Working Papers at Chicago Unbound. It has been accepted for inclusion in Public Law and Legal Theory Working Papers by an authorized administrator of Chicago Unbound. For more information, please contact unbound@law.uchicago.edu. 


\title{
CHICAGO
}

Public LaW and Legal Theory Working Paper No. 94

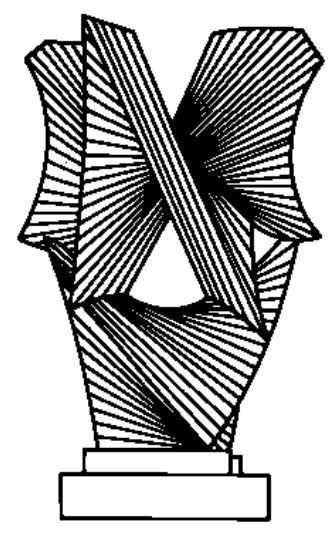

\section{A GAINST PREDICTION: \\ Sentencing, Policing, AND Punishing in An ACtuARial AGE}

\author{
Bernard E. Harcourt
}

THE LAW SCHOOL THE UNIVERSITY OF CHICAGO

May 2005

This paper can be downloaded without charge at the Public Law and Legal Theory Working

Paper Series: http://www.law.uchicago.edu/academics/publiclaw/index.html and The Social Science Research Network Electronic Paper Collection: http://ssrn.com/abstract_id=756945 


\title{
AGAINST PREDICTION:
}

\section{Sentencing, Policing, And Punishing in An Actuarial Age}

\author{
BERNARD E. HARCOURT \\ UNIVERSITY OF CHICAGo LAW SCHOOL
}

Paper Presented at the Criminal Justice Roundtable

Harvard Law School

May 13, 2005 


\begin{abstract}
Actuarial methods-i.e. the use of statistical rather than clinical methods on large datasets of criminal offending rates to determine different levels of offending associated with one or more group traits, in order to (1) predict past, present or future criminal behavior and (2) administer a criminal justice outcome-now permeate the criminal law and its enforcement. With the single exception of racial profiling against AfricanAmericans and Hispanics, most people view the turn to the actuarial as efficient, rational, and wealth-maximizing. The fact is, law enforcement agencies can detect more crime with the same resources if they investigate citizens who are at greater risk of criminal offending; and sentencing bodies can reduce crime if they incapacitate citizens who are more likely to recidivate in the future. Most people believe that the use of reliable actuarial methods in criminal justice represents progress. No one, naturally, is in favor of incorrect stereotypes and erroneous predictions; but, to most people, it makes sense to decide who to search based on reliable predictions of criminal behavior, or to impose punishment based on reliable estimates of reoffending.
\end{abstract}

This article challenges our common sense. It sets forth three compelling reasons why we should be skeptical about-rather than embrace - the new actuarial paradigm. First, the reliance on predictions of future offending may be counterproductive to the primary goal of law enforcement, namely fighting crime. Though this may seem counterintuitive, it is, surprisingly, correct: the use of actuarial methods may increase the overall amount of the targeted crime depending on the relative responsiveness of the targets (in comparison to the responsiveness of non-targeted citizens) to the changed level of law enforcement. The overall impact on crime depends on how the members of the different groups react to changes in the level of enforcement: if the profiled persons are less responsive, then the overall amount of profiled crime in society will likely increase.

Second, the reliance on probabilistic methods produces a distortion of the carceral population. It creates a dissymmetry between the distribution of actual offenders and of persons who have contact with the criminal justice system through arrest, conviction, incarceration, or other forms of supervision and punishment. It produces a disproportionate rate of correctional contacts among members of the profiled group in relation to their representation in the offending population. This, in turn, compounds the difficulty of many members of targeted groups to obtain employment, pursue educational opportunities, or lead normal family lives. It represents a significant social cost that is often overlooked in the crime and punishment calculus.

Third, the proliferation of actuarial methods has begun to bias our conception of just punishment. The perceived success of predictive instruments renders more appealing theories of punishment that function with prediction. It renders more natural theories of selective incapacitation and sentencing enhancements for citizens who are at greater risk of future dangerousness. In sum, it reshapes the way we think about just punishment. Yet the development of these actuarial devices are fortuitous advances in technical knowledge from disciplines such as sociology, psychology, and police studies that have no normative stake in the direction of our criminal laws and punishments. These 
technological advances represent, in this sense, exogenous shocks to our legal system. And this raises very troubling questions about what theory of just punishment we would independently embrace and how it is, exactly, that we have allowed technical knowledge, somewhat arbitrarily, to dictate the path of justice.

Instead of embracing the actuarial turn in criminal law, we should rather celebrate the virtues of the random: randomization, it turns out, is the only way to achieve a carceral population that reflects the offending population. As a form of random sampling, randomization in policing has significant positive value: it reinforces the central moral intuition in the criminal law that similarly situated individuals should have the same likelihood of being apprehended if they offend-regardless of race, ethnicity, gender or class. It is also the only way to alleviate the counter-effect on overall crime rates that may result from the different responsiveness of different groups to policing. Randomness in the policing context is simple: law enforcement could use a lottery system for IRS audits, random selection for airport screening, or numerical sequencing for consensual car searches on the highway. In the sentencing area, randomness means something quite different, but no less straightforward: it means imposing a sentence based on a proper metric and then avoiding the effect of prediction by eliminating parole or other devices that are prediction-based. Randomness does not mean drawing names out of a hat in deciding who to parole or how long to sentence. It means, instead, eliminating the effect of prediction.

In criminal law and enforcement, the presumption should be against prediction. Actuarial methods should only be employed when it can be demonstrated to our satisfaction that they will promote the primary interest of law enforcement without imposing undue burden or distorting our conceptions of just punishment. Barring that, criminal law enforcement and correctional institutions should be blind to prediction. 


\section{INTRODUCTION}

Case \#1: The Internal Revenue Service receives approximately 130 million individual tax returns per year, but only has the resources to audit about 750,000 or 0.6 percent of those filings - about 1 in 170. In order to enhance its ability to detect tax evasion, the IRS has developed a complex and "top secret" computer algorithm that predicts likely cheating electronically. Each return is fed into a computer in Martinsburg, West Virginia, and the computer assigns a score based on the algorithm — an algorithm guarded like the CocaCola formula. "The higher the score, the more likely a return will be selected for an audit," the IRS explains. ${ }^{1}$

The algorithm is known as the "Discriminant Index Function" or "DIF." The DIF is based on multiple-regression analysis of past audits intended to identify the key factors that are most likely to indicate tax fraud. The DIF was last updated in 1992 based on a regression analysis of approximately 50,000 tax returns that had been randomly audited in 1998. The DIF is an expense-based scoring model that looks at the actual items on a tax return, rather than on failures to report items. (Another filter, the UIDIF, was developed around 2000 to pick up returns that fail to report items reported on other forms, such as W-2s, 1099s, and 1098s).

The Discriminant Index Function compares the tax return under review with average returns in the same income bracket and profession, and identifies outliers. It assigns a number value to suspicious items on the tax return, and then produces a score that represents the estimated probability of noncompliance. Typical items that may raise a red flag-according to leaked information-include high, above-average levels of itemized deductions and Schedule C filings. When the DIF score exceeds the IRS target, the tax return is reviewed manually by an IRS agent in order to determine whether it should be audited. Depending upon the problems detected, the return will be sent to an IRS Service Center or an IRS district office. Those returns that fit the profile are more likely to be examined. The IRS uses the DIF system to select around 20 to 30 percent of the tax returns that are audited each year in the United States. ${ }^{2}$

\footnotetext{
${ }^{1}$ IRS spokesman in St. Paul, Minn., Bill Knight, as reported in Maura Lerner, "Who gets audited up to science," The Arkansas Democrat-Gazette, April 17, 2000 (p. D3).

2 Susan Scherreik, "The Tax Man Still Biteth," Business Week, February 28, 2000 (No. 3670, p. 162) (the IRS used the DIF to select 29 percent of returns audited in 1998).
} 
Case \#2: In the early 1970s, DEA agents John Marcello and Paul Markonni started identifying the common characteristics of illegal drug couriers disembarking from planes at U.S. airports. "The majority of our cases, when we first started," Markonni explains, "involved cases we made based on information from law enforcement agencies or from airline personnel. And as these cases were made, certain characteristics were noted among the defendants." 3 Those characteristics eventually became known as the drugcourier profile, first implemented in a surveillance and search program at the Detroit airport in the fall of 1974.

The profiles first used in the Detroit experiment were based on empirical observations collected over eighteen months of surveillance at the airport, observations that focused on the conduct and appearance of travelers. The experiment was deemed a success, and the program went nationwide. Between 1976 and 1986 there were in excess of 140 reported court decisions involving DEA stops of passengers at airports across the country based on the drug-courier profile.

In 1982, the National Institute of Justice - the research arm of the Department of Justice-conducted a systematic study of the drug-courier profile. ${ }^{4}$ The study required DEA agents to fill out a report for all encounters they instigated and a log of passengers observed during an eight month period in 1982. Of about 107,000 passengers observed, the agents approached 146. According to the report, most of the encounters (120 of the total 146) were triggered by a combination of behavioral and demographic peculiarities of the passengers - matches to a profile. The results were as follows:

$\begin{array}{lll} & \text { Number } & \text { Percentage } \\ \text { Total passengers stopped } & 146 & 100 \% \\ \text { No search after questioning } & 42 & 29 \% \\ \text { Consent searches } & 81 & 55 \% \\ \text { Searches with warrant or incident to arrest } & 15 & 10 \% \\ \text { Contraband found or other evidence of crime } & 49 & 34 \%\end{array}$

\footnotetext{
${ }^{3}$ Charles L. Becton, The Drug Courier Profile: 'All Seems Infected That Th' Infected Spy, As All Looks Yellow to the Jaundic'd Eye, 65 N.C.L.REV. 417, 426 (__ $)$.

${ }^{4}$ See Zedlewski, The DEA Airport Surveillance Program: An Analysis of Agent Activities (1984), reported in J. Monahan \& L. Walker, Social ScienCe in LaW: CASES AND Materials 404437 ( $5^{\text {th }}$ edition 2002).
} 
Case \#3: In Kansas, the sentencing commission is required by statute annually to prepare two-year projections of the expected adult prison population. When its projections exceed available prison-bed capacity, the commission has to identify ways of either reducing the number of inmates admitted to prison or adjusting the length of their prison sentences. In fiscal year 2002, with dire projections of an unprecedented number of prisoners, the Kansas legislature followed the lead of California and Arizona, and instituted mandatory drug abuse treatment in lieu of incarceration for a designated group of drug offenders convicted after November 1, 2003..$^{5}$ Other states faced with similar prison-capacity constraints, such as Louisiana and Alabama, have enacted early release legislation. Those statutes make possible outright release from prison in order to alleviate overcrowding. ${ }^{6}$

In general, candidates for early release or diversionary programs must satisfy strict risk-of-reoffending criteria. For example, in Kansas, to be eligible for drug treatment in lieu of incarceration, the offender must have been convicted of drug possession only. Drug sales or trafficking preclude diversion, as do prior violent felonies and posing a significant threat to public safety. To assess the latter, the Kansas legislature mandates that each candidate for treatment be subject to what they refer to as "a statewide, mandatory, standardized risk assessment tool."7 That risk assessment tool, in Kansas, is the Level of Services Inventory Revised-known in the business as the LSI$\mathrm{R}$ - and the results of the assessment are incorporated into the pre-sentence investigation report submitted to the sentencing judge. From November 2003 to mid-January 2004, 149 drug convicts in Kansas were diverted to treatment.

The LSI-R was developed in Canada in the late 1970s and is today utilized in nearly all of the U.S. states and the Canadian provinces at some juncture in the postconviction process - for the security classifications of prison inmates, for levels of probation and parole supervision, or as a factor for determining eligibility for parole. In many states, the LSI-R is administered for multiple purposes. It is championed as a versatile and cost-effective tool for predicting risk and assessing needs. So, for instance, in Pennsylvania, the LSI-R score is a component of a number-based decision matrix for

\footnotetext{
5 Patricia Biggs, Executive Director, Kansas Sentencing Commission, "SB 123 Background \& Offender Flow," Report prepared on behalf of the Kansas Sentencing Commission, at page 4.

6 See James Austin and Patricia L. Hardyman, "The Risks and Needs of the Returning Prisoner Population," The Review of Policy Research, No. 1, Vol. 21, p. 13 (2004).

${ }^{7}$ See Kansas Senate Bill 123, New Section 1(b)(2) (2003).
} 
deciding whether an inmate is paroled. In Washington state, the Indeterminate Sentence Review Board, assigned responsibility for determining parole eligibility for all offenders who committed their crime prior to July 1, 1984, uses the LSI-R. In North Dakota, the parole board considers the results of the LSI-R when making its decisions to parole someone-along with the availability of treatment programs, the nature of the offense, the inmate's prior record, and an evaluation of how well the inmate did under the terms of any prior parole and probation supervision. In Alaska, the parole board may give the LSI-R score up to 35 percent weight in its decision. In Vermont, the LSI-R is one of the primary factors in the decision of the parole board. In Oklahoma, active supervision of parole cannot be terminated without an LSI-R score below a designated number.

These three cases reflect one of the most striking trends in law enforcement and punishment at the turn of the twenty-first century: risk assessment, algorithms, and criminal profiles - in sum, the use of actuarial methods - have grown exponentially and now dominate the field of crime and punishment. The trend is visually dramatic and reflected well, for instance, in the case of parole authorities using parole-prediction instruments:

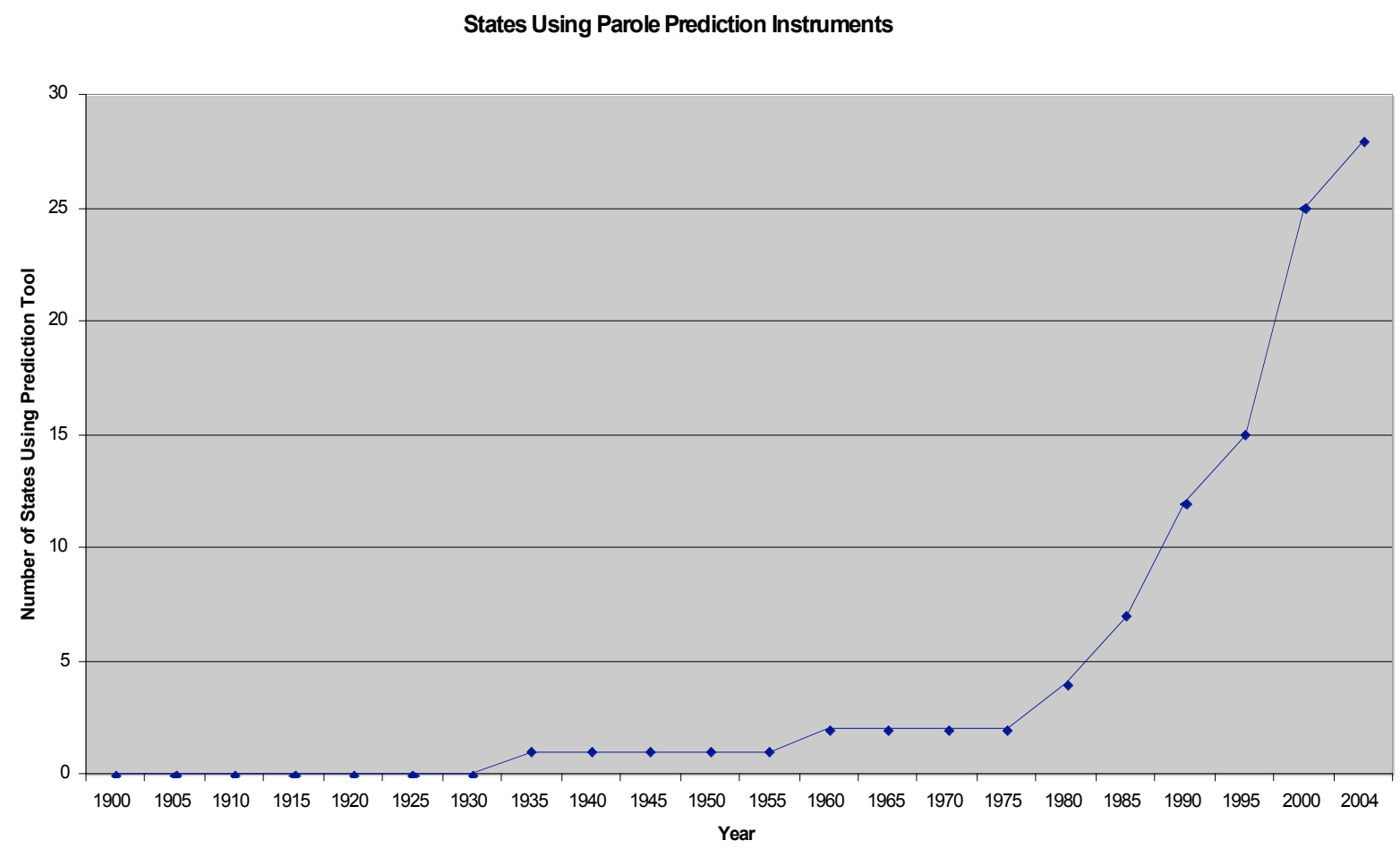


Illinois alone accounted for the only use of an actuarial instrument throughout the 1930s, 40s, and 50s. Ohio experimented with a risk assessment tool in the 1960s, and California began using a prediction tool in the early 1970s — as did the federal government. While some states, such as Illinois and California, later stopped using actuarial methods when they abandoned parole, other states, such as Georgia, Iowa, Tennessee, South Carolina, Alabama and Florida, began using risk assessment tools in the late 1970s and early 1980s. Soon, many other states followed their lead-including Missouri, Michigan, North Dakota, South Dakota, Washington, Arkansas, Colorado, Nevada, Maryland, Connecticut, New Jersey, Ohio, Vermont, Alaska, Idaho, Kentucky, Maine, Montana, Pennsylvania, Texas, Utah, and Delaware.

What is especially remarkable about this particular case is that it coincided with the relative demise of parole. The number of states with parole declined steadily from about 44 in 1979 to about 32 in 2003. Despite this decline, the number of states with parole that used an actuarial method increased from about 1 in 1979 to 23 in 2004. The trend, again, is truly dramatic especially if one looks at the proportion within states that maintain an active parole system:

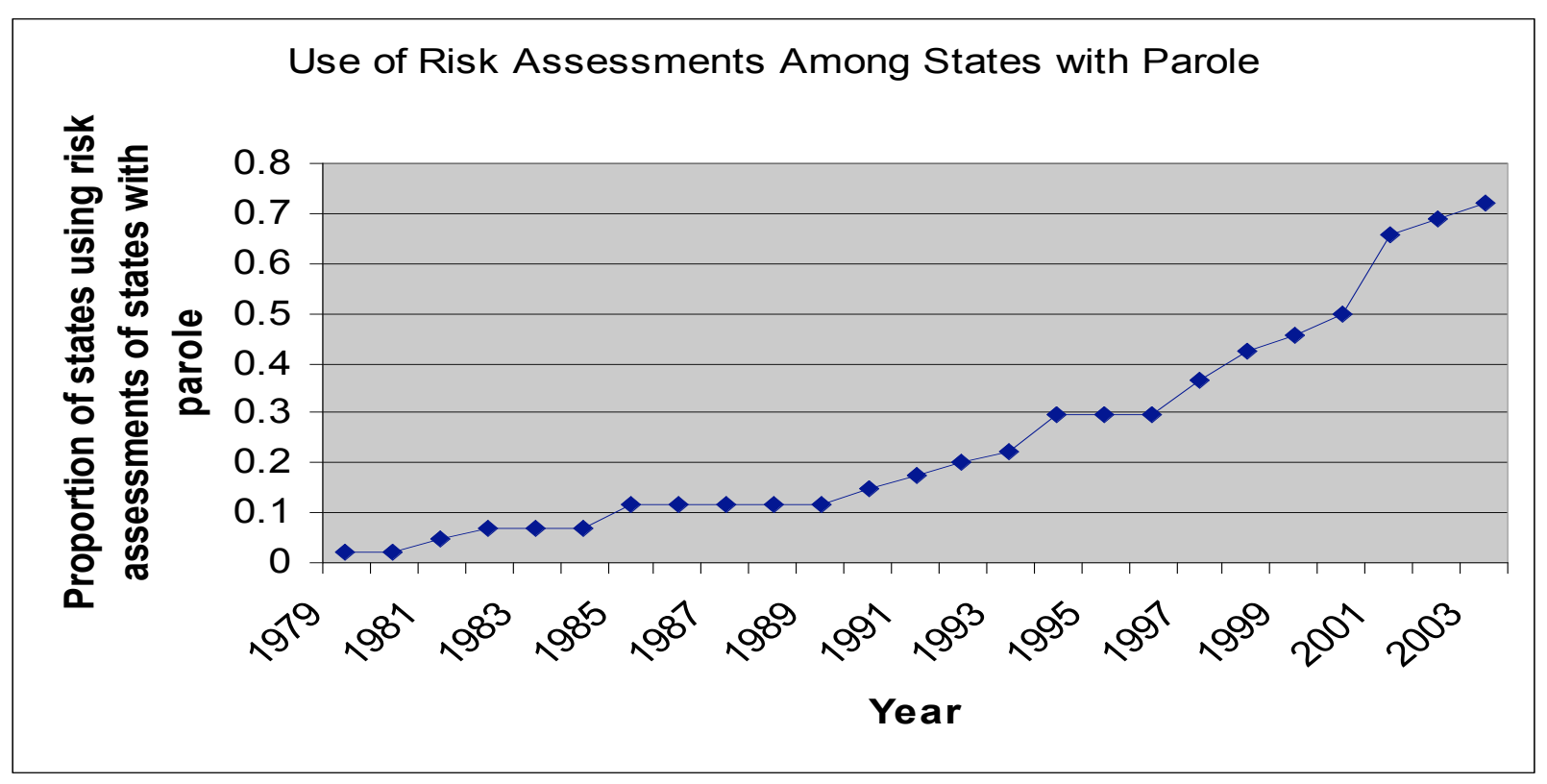


In 2004, 28 states used risk assessment tools to guide their parole determinations, representing approximately 72 percent of states that maintain an active parole system. As a leading parole authority association suggests, "In this day and age, making parole decisions without benefit of a good, research-based risk assessment instrument clearly falls short of accepted best practice."

The same trend can be identified in a number of other criminal law contexts, such as the increased use of criminal profiling in law enforcement-from IRS audits, to airport searches, to traffic stops - as well as the increased popularity of selective incapacitation, sentencing enhancements for habitual offenders, "three-strikes" laws, and even postconfinement civil commitment for sexually violent predators. Habitual offender statutes, already popular in the 1940s, experienced a renaissance in the $1990 \mathrm{~s}$ beginning in Washington state and soon followed by the notorious "three-strikes" law passed in California. ${ }^{9}$ Even in the civil category, sixteen states now impose commitment based on likelihood of future sexually violent re-offending, and fourteen of those states enacted their statutes in the 1990s. ${ }^{10}$

I label these methods "actuarial" in a very narrow and specific sense. They are actuarial insofar as they use statistical methods - rather than clinical methods - on large datasets of criminal offending rates, in order to determine the different levels of offending associated with a group or with one or more group traits, and, based on those correlations, to predict first the past, present or future criminal behavior of a particular individual and to administer second a criminal justice outcome for that particular individual. These methods use predictions about the criminality of groups or group traits to determine criminal justice outcomes of particular individuals within those groups. The I.R.S. Discriminant Index Function is actuarial in precisely this narrow sense: it uses the greater statistical likelihood of tax evasion among a group of tax filers in order to predict past or current behavior (namely tax evasion) of any particular tax filer, and to decide a

\footnotetext{
${ }^{8}$ Handbook for New Parole Board Members, Chapter 4: Parole Decisionmaking, at page 35, Association of Paroling Authorities International.

${ }^{9}$ See generally, Franklin Zimring, Gordon Hawkins, and Sam Kamin, Punishment and Democracy: Three Strikes and You're Out in California (Oxford University Press 2001); Victoria Nourse, Symposium essay in the Tulsa Law Review (Summer, 2004).

${ }^{10}$ W. Lawrence Fitch \& Debra A. Hammen, "The New Generation of Sex Offender Commitment Laws: Which States Have Them and How Do They Work?" in Protecting Society from Sexually Dangerous Offenders, Ch 1. (Bruce J. Winick \& John Q. LaFond eds., 2003).
} 
criminal justice outcome (namely whether or not to audit their tax return). The drugcourier profile is actuarial in the same way: it uses the statistical likelihood of being a drug-courier based on group demeanor evidence in order to predict whether an individual is a drug trafficker and to decide whether to administer a police search. Similarly, parole prediction instruments use group-trait statistics from large datasets of parolee violation rates to predict whether a particular inmate will violate parole and determine whether or not to release that inmate on parole; and selective incapacitation uses group-trait statistics to identify whether a convict will more likely recidivate, in order to determine how long to incarcerate that individual. The federal sentencing guidelines also qualify as actuarial insofar as they rely on the factor of prior criminal history to predict future criminality and to determine the proper length of sentence for each individual convicted of a federal offense.

I use the term "actuarial" in this narrow and limited sense so as not to include many other criminal justice outcomes that are also based on probabilities. The truth is, most criminal justice determinations rest on probabilistic reasoning. The jury's verdict at trial, for instance, is nothing more than a probabilistic determination of prior fact. So is a police officer's determination whether there is sufficient cause to search or arrest a suspect, a judge's decision whether a suspect was coerced to confess, or even a forensic laboratory's conclusion regarding a DNA match—or DNA exoneration. In all these more general cases, the decision maker renders a factual finding using a legal standard"beyond a reasonable doubt," "probable cause," "a preponderance of the evidence," or "clear and convincing evidence" - that essentially translates a probability into a legal conclusion.

These more general cases of probabilistic reasoning in criminal law, however, do not qualify as "actuarial" because they do not rely on statistical correlations between a group trait and that group's criminal offending rate. A jury's decision to overwhelmingly credit (for example, with 98 percent certainty) an eye-witness identification of height, race and gender (for instance, an identification of an offender as a tall white male) does create three relevant group traits for purposes of the ultimate probabilistic determination of culpability. If the accused is indeed tall, white and male, the jury will no doubt use these group traits as part of its ultimate calculus whether the accused is guilty beyond a 
reasonable doubt. But not because of any higher offending rates of tall white males in genera versus, for instance, women. Not because of any general correlations between the group traits and offending rates. The jury will use height, race and gender because those categories help to delimit in probabilistic terms the pool of possible suspects. Similarly, DNA evidence does rely on group traits and group probabilistic determinations, but does not concern itself with the offending rates of any group — only with probable membership in a group.

I reserve the term "actuarial," then, for the narrower set of criminal justice determinations that do not rest on probabilities tout court, but rather on statistical correlations between group traits and group criminal offending rates. There is absolutely no way to avoid using probabilities in the larger category of criminal justice determinations. A jury's determination of prior fact or a police officer's determination of probable cause is and will always remain - at least in the foreseeable future - an odds determination. But again, in contrast, it is possible-and I argue in this article advisable - to avoid reliance on probabilistic determinations of an actuarial nature.

A number of prominent scholars have identified and discussed the turn to the actuarial and often cast it in dark terms. ${ }^{11}$ Often, but not always. In the criminal profiling context - specifically in the racial profiling debates - an emerging consensus among economists is that racial profiling does not necessarily reflect invidious discrimination on the part of the police, but may be consistent instead with an honest and good faith effort to increase the success rate of searches. ${ }^{12}$ Thus, even if the police search a

\footnotetext{
${ }^{11}$ The turn to managerial and administrative measures was at the heart of Michel Foucault's work Discipline and Punish (1976), and has been discussed by many prominent scholars and critics of our new disciplinary age. See generally David Garland, The Culture of Control; Stanley Cohen, Visions of Social Control; John Pratt, Dangerous Offenders; Malcolm M. Feeley and Jonathan Simon, The New Penology: Notes on the Emerging Strategy of Corrections and Its Implications, 30 Criminology 449, 450B452 (1992); Stuart A. Scheingold, Constructing the New Political Criminology: Power, Authority, and the Post-Liberal State, 23 Law \& Social Inquiry 857, 866B69, 882B86 (1998); Katherine Beckett, Making Crime Pay: Law and Order in Contemporary American Politics, 10 (New York: Oxford University Press 1997); Loïc Wacquant, $L=$ ascension de $l=E$ État pénal en Amérique, 124 Actes de la recherche en sciences sociales 7 (1998).

${ }^{12}$ The leading studies include John Knowles, Nicola Persico, and Petra Todd, Racial Bias in Motor Vehicle Searches: Theory and Evidence, 109 J Pol Econ 203 (2001); Rubén Hernández-Murillo and John Knowles, Racial Profiling or Racist Policing?: Testing in Aggregated Data (working paper Apr 18, 2003), online at http://www.econ.upenn.edu/ jknowles/Research/HKRacProf_2003c.pdf (visited June 5, 2004); Nicola
} 
disproportionate number of minorities, some economists assert, the profiling is only demonstrably racist — and thus problematic — if the rate of successful searches of minority suspects is lower than the rate of successful searches of white suspects. Otherwise, disproportionate searches of minorities are consistent with policing efficiency and do not necessarily demonstrate invidious bias.

Others defend the rise of the actuarial in more general terms - while carving out specific exceptions for generalizations based on race, gender or sexual orientation. Frederick Schauer in Profiles, Probabilities, and Stereotypes (2003) offers a generalized, but nuanced, defense of actuarial reasoning. "In this book," Schauer explains, "I defend the morality of decision by categories and by generalizations, even with its consequent apparent disregard for the fact that decision-making by generalization often seems to produce an unjust result in particular cases."13 Schauer sets aside generalizations based on race, gender and sexual orientation as most often problematic, but argues that these are the exceptional cases of generalization, and that it would be wrong to generalize from them to the vast majority of nonspurious generalizations. "[T] he problems with racial profiling are not problems of profiling, with race being merely an example. Rather," Schauer claims, "the problem is about race and not about profiling. Once we comprehend the ubiquity and inevitability of profiling, we see that the objection to racial profiling, when valid, will treat the racial component and not the profiling component of racial profiling as crucial."14 A lot of profiles, Schauer suggests, are simply prudent and efficient ways of dealing with a complex world. "My aim in this book," Schauer declares, "is to challenge the primacy of the particular." 15

Schauer contends that he is in the minority and that, today, it is far more fashionable to favor the individual and frown on stereotypes. There has been a turn to the particular, he maintains, especially in law where the focus is always on "this particular case" or "these particular facts": "The modern idea is that this particular case, or this

Persico, Racial Profiling, Fairness, and Effectiveness of Policing, 92 Am Econ Rev 1472 (2002); Vani K. Borooah, Racial Bias in Police Stops and Searches: An Economic Analysis, 17 Eur J Pol Econ 17 (2001).

${ }^{13}$ Frederick Schauer, Profiles, Probabilities, and Stereotypes ix (Harvard University Press 2003).

${ }^{14}$ Schauer 2003:197-198.

${ }^{15}$ Schauer 2003:ix. 
particular event, is what is most important, and that making the right decision for this case or on this occasion is the primary building-block of just behavior." 16

To be sure, Schauer is no doubt correct that the language of legal decision-making is strongly case specific. The common law method of applying precedent to the specific facts of a case in controversy is a particularistic endeavor. But outside the narrow confines of the judicial decision-making process, I would argue, the vast majority of our judgments in criminal law enforcement and policy fall in the category of the generalization, stereotype, and profile; and, with the possible exception of racial profiling, we generally tend to be comfortable with these types of generalization. The general public and most academics generally support the use of prediction in policing and sentencing. To most, it is a matter of plain common sense: why would we not use our best social science research and most advanced statistical methods to improve the efficiency of police investigations, sentencing decisions, parole practices, treatment efforts, and general correctional procedures? Why wouldn't we deploy our wealth of new knowledge to fight crime more effectively? It would be crazy not to take advantage of what we now know about the propensity to commit crime.

Contrary to what Schauer suggests, his $i s$ the majority view. It has become, today, second nature to believe that actuarial methods enhance the efficiency of our carceral practices with few offsetting social costs - again with the exception, for some, or at least publicly, of racial profiling. To most, criminal profiling on a nonspurious trait will simply increase the detection of crime and render police searches more successful, which inevitably will reduce crime rates. Although racial profiling may be suspect because of the sensitive issues surrounding race, other forms of criminal profiling - profiling the rich for tax audits, for instance-do not raise similar concerns. There, the calculus is selfevident: the detection of crime will rise, the efficiency of law enforcement will increase, and, through the traditional mechanisms of deterrence and incapacitation, crime rates will decrease. Most people believe this. In fact, even the staunchest, most vocal opponents of racial profiling support criminal profiling more generally. ${ }^{17}$

\footnotetext{
${ }^{16}$ Schauer 2003:ix.

${ }^{17}$ See, e.g., DAVID Harris, ProfiLES IN INJUSTICE 16 (2002).
} 
And they have it all wrong. This article challenges our common sense. It challenges the majority position that most actuarial methods are beneficial to society. The problems that are most often raised in the racial profiling context, I contend, are problems about criminal profiling more generally. Actuarial methods in the criminal justice field produce hidden distortions with significant costs to society. We would be better off as a society if we deployed our criminal justice measures more randomly.

In this article, I do not simply identify, label, or trace the actuarial turn. Instead, I argue against the actuarial turn. And the argument does not rest on the traditional value associated with individualized decision making or the importance of paying attention to the particular. No, the argument is not about the particular versus the general. Paradoxically, the actuarial grew out of our desire to individualize. It represents the highest fulfillment of our aspiration to respect the particular. It is the very concern, the obsession with the individualization of punishment that led us down the actuarial path. No, this is not a debate about the particular versus the general at all. It is a debate, instead, about mathematics, identifiable social costs, and epistemic consequences for our shared conceptions of just punishment. Let me begin, though, with the mathematics.

\section{The Mathematics of Criminal Profiling}

One of the strongest arguments for the use of predictive methods in criminal law enforcement comes from rational action theory: assuming that potential offenders respond rationally to the probability of detection and punishment, then targeting law enforcement on members of a higher-offending population will not only increase the amount of crime detected, but more importantly decrease the offending rate among those members of the targeted group by increasing the cost of deviate behavior. In its purest form, the economic model of crime suggests that the government should target higheroffending populations until the point where their offending rates have fallen to the same level as the general population. At that point, the government maximizes the effectiveness of its law enforcement practices. 


\section{(a) Policing and Law Enforcement}

I have set forth in great detail the logic of this deterrence argument using the specific case of racial profiling in an article titled Rethinking Racial Profiling: A Critique of the Economics, Civil Liberties, and Constitutional Literature, and of Criminal Profiling More Generally. ${ }^{18}$ Let me incorporate here, for simplicity, the one graph that visually explains the rational choice argument. I include the graph infra on page 20.

The graph shows the relationship between the internal rate of searches conducted within each racial group and the offending rate of these different racial groups. At Time 1 , the police are not engaged in profiling of any sort: the police are searching all racial groups at the same internal search rate of 10 percent. The graph reflects the basic assumption of nonspurious profiling, namely that minorities are offending at a higher rate than whites-6 percent versus 4.5 percent-resulting in higher hit rates for minority searches.

Given the higher marginal hit rate for minorities, the police may begin to search minorities more than their share of the available population, and, as the proportion of searches targeting minorities increases, the offending rate of minorities decreases. The police continue to search marginally more minorities until Time 2 when the offending rates for whites and minorities are the same -5 percent. Now the police are using race in the decision to search: the police are searching 20 percent of the available minorities and 7.5 percent of the available whites, resulting in a hypothetical total distribution of searches of, say, 60 percent minorities and 40 percent whites. At that distribution of searches, the offending rates are similar - and, one can infer, so are the hit rates. At that distribution, the efficient police officer has no reason to change the racial distribution of searches: the officer has no incentive to search more minorities than the $60 / 40$ total distribution, which produces these different internal group search rates.

If the police officer is, in fact, searching more minorities and getting to Time 3 , where the offending rate of minorities is lower than that of whites- 4.8 percent versus 6 percent - then the officer must be racially prejudiced. The only reason that the officer would search more minorities than at the Time 2 equilibrium - that is, would search, say,

${ }^{18} 71$ The University of Chicago Law Review 1275 (2004). 
70 percent minorities and 30 percent white, instead of the Time 2 distribution of 60/40is if the officer had a taste for discrimination resulting in higher utility even though less minorities are offending and thus less searches are successful. ${ }^{19}$

The three hypothetical distributions of searches-20/80, 60/40, and 70/30correspond to three different sets of internal group search rates (internal to the different racial groups). These three scenarios also correspond to the three equilibrium points for the color-blind, efficient, and racist police officer. The three time points are represented in the following graph:

GRAPH: The Economic Model of Racial Profiling

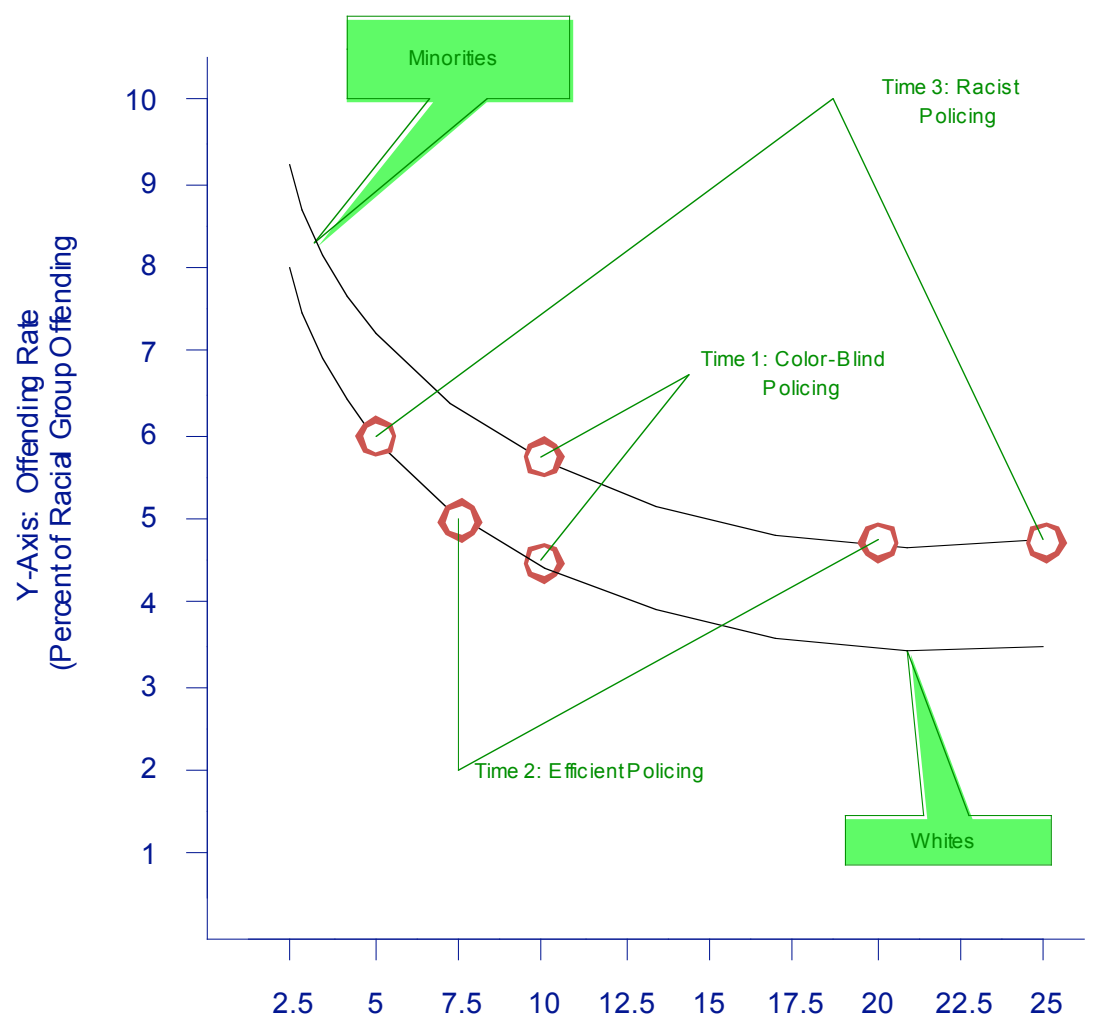

X-Axis: Internal Group Rate of Searches (Percent of Searches Conducted Within Racial Group)

19 As evidenced here, the model relies principally on Gary Becker's seminal work on tastes for discrimination. See generally Gary Becker, Accounting for Tastes (Harvard 1996). 
The problem is, this economic model of racial profiling rests on a crucial assumption that is unfounded and likely wrong in many circumstances, namely, that the different groups react similarly to the change in policing. This is what we call, in more technical jargon, the relative elasticity of offending to policing — or elasticity for shortof the two groups. The elasticity of offending to policing is the degree to which changes in policing affect changes in offending. So for instance, if the IRS targets drywall contractors or car dealers for audits of their tax returns - as they did in the mid-1990s we expect that there will be less tax evasion by drywall contractors and car dealers. We assume that their tax evasion is elastic to policing and will fall with the enhanced scrutiny. It is the elasticity that reduces the offending of the targeted group-those identified by the actuarial method.

But even if we assume elasticity of offending to policing among drywall contractors and car dealers, society as a whole will only benefit from their decrease in tax evasion if the non-profiled groups do not begin to evade their tax burden more, in absolute numbers, because they feel immune from scrutiny-in other words, because of their elasticity to reduced enforcement. Accountants and bankers, for instance, may realize that they are less likely to be audited, and may therefore cheat a bit more on their taxes. What matters, then, is the relative elasticity of the two groups, profiled (drywall contractors and car dealers) and non-profiled (accountants and bankers). If the targeted group members have lower elasticity of offending to policing - if their offending is less responsive to policing than other groups - then targeting them for enforcement efforts will likely increase the overall amount of crime in society because the increase in crime by accountants and bankers will exceed the decrease in crime by drywall contractors and car dealers. In raw numbers, the effect of the profiling will be greater on the more elastic non-profiled and smaller on the less elastic profiled group.

To make matters worse, there is no good reason to assume that the higheroffending group is as responsive to policing as others. After all, we are assuming that the two groups have different offending rates. Whether it is due to different socio-economic backgrounds, to different histories, cultures, or education, nonspurious profiling rests on the nonspurious assumption that one group of individuals offends more than another, 
holding everything else constant. If their offending is different, then why would their elasticity be the same? If they are, for instance, offending more because they are socioeconomically more disadvantaged, then it would follow logically that they may also have less elasticity of offending to policing because they have fewer alternative job opportunities. For some drywall contractors, for instance, it may only be possible to pay their bills and employees by evading taxes, whether because of their socio-economic condition or because the tax laws were not written with the economics of drywall contracting in mind.

The bottom line, then, is that if the profiled group has lower elasticity of offending to policing, profiling that group will probably increase the amount of crime in society. I demonstrate this with mathematical equations in Rethinking Racial Profiling, but believe that the proof is captured well simply by modifying the earlier graph to reflect different elasticities: 
GRAPH: Racial Profiling with Different Elasticities

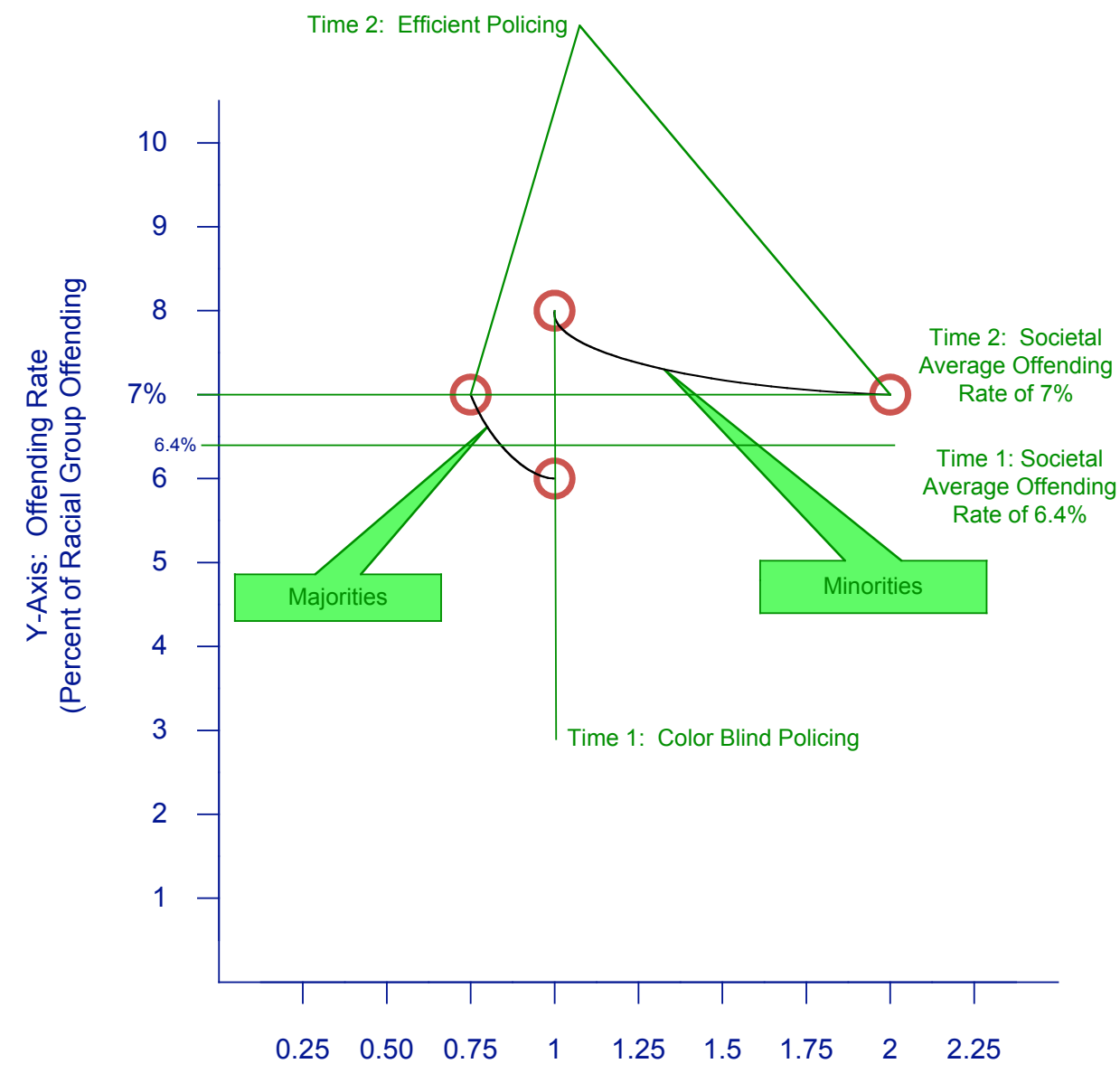

X-Axis: Internal Group Rate of Searches (Percent of Searches Conducted Within Racial Group)

In essence, so long as the equilibrium point in offending at Time 2 is achieved above the average offending rate at Time 1, the profiling will produce increased crime in society.

\section{(b) Sentencing Matters}

This first, mathematical critique of the use of actuarial methods is intuitively clear in the context of racial profiling and, more generally, criminal profiling. As long as there is some reason to believe that there are different offending rates as between different groups-whether racial groups, classes, or employment clusters-there is also some 
reason to expect different elasticities of offending to policing. And if there are indeed different elasticities, there is no good reason to believe that the profiling will reduce overall crime in society.

At first blush, it may be tempting to think that none of this applies to the situation of sentencing, parole, or selective incapacitation. After all, there is no doubt that lengthening the sentence of a likely repeat offender is not going to increase overall crime in society. And it is, indeed, true that there is a slight difference between the use of actuarial methods in policing and in the sentencing context. In the policing contextracial profiling, IRS Discriminant Index Function, or drug-courier profiles - the actuarial tends to focus on predicting past or present behavior in order to determine the criminal justice outcome, such as whether to search, audit, or investigate. In contrast, in the sentencing context-parole prediction, sentencing guidelines, or selective incapacitation-the actuarial methods tend to focus on predicting future criminal behavior in order to determine a criminal justice outcome, such as whether to parole or how long to sentence. Doesn't this difference-however slight - change the crime and punishment equation?

Though somewhat counter-intuitive, the fact is that the very same problem plagues the sentencing context. If we assume rational action and have reason to believe that there are different offending rates and elasticities as between high-risk recidivist inmates and low-risk first-offender types, then the use of actuarial methods will affect them in the same way it affects the different populations in the racial profiling example: low-risk first-offenders are likely to offend more on a first time basis if their sentence is relatively reduced, and their greater overall offending is likely to outweigh the reductions in crime by less elastic, high-risk recidivists, resulting in higher overall crime in society, if indeed these first-offenders are more elastic to sentencing. The analysis is identicalthough perhaps admittedly less intuitive. Let me slow this down and take it frame-byframe.

For purposes of this first mathematical critique, we are again assuming a rational actor model. We are assuming that people are deterred by more punishment, by a longer sentence, by the higher costs associated with conviction of a crime. In terms of deterrence, the parole decision-making example is in fact the perfect illustration of 
increasing or decreasing the cost of crime. The parole determination will affect the length of the expected prison sentence: granting parole will reduce the length, and denying parole will extend the length of the expected sentence. If offending is elastic to punishment (the core assumption of the economic model of crime pioneered by Gary Becker and Richard Posner), then we would expect that, in response to parole profiling, offending by first-time offenders will increase (since they now expect relatively less punishment), and offending by recidivists to decrease (since they now expect longer punishment).

The case of parole prediction, it turns out, works in exactly the same way as criminal profiling: overall crime in society would increase if the elasticity of the recidivists is lower than the elasticity of the first-time offenders-which we could easily assume if they do in fact have different offending rates. Again, a graph based on a simple hypothetical will demonstrate the possible effect in the case of parole-prediction determinations.

Imagine that the world is made up of two types of people. Members of one group are characterized by lower rates of criminal offending and the likelihood that if they do offend and are caught, they will not likely reoffend-I will call these "ordinary" citizens. Members of the second group are characterized by higher overall rates of offending in part because they are likely to reoffend even after they have been incarcerated-I call these "recidivists." Increasing the length of the prison sentence of the recidivists-either at sentencing or later by denying them parole - is likely to increase the cost of criminal behavior to those individuals. Assuming rational action, the most efficient distribution of punishment would entail lengthening the sentence of the recidivists until the point where their offending rates fall to the same rate as that of ordinary citizens. At that point, there will be no benefit to imposing lengthier sentences on members of either group. Here too, though, the overall effect on crime will depend on the relative elasticities of members of the two groups to punishment: 
GRAPH: Criminal Sentencing

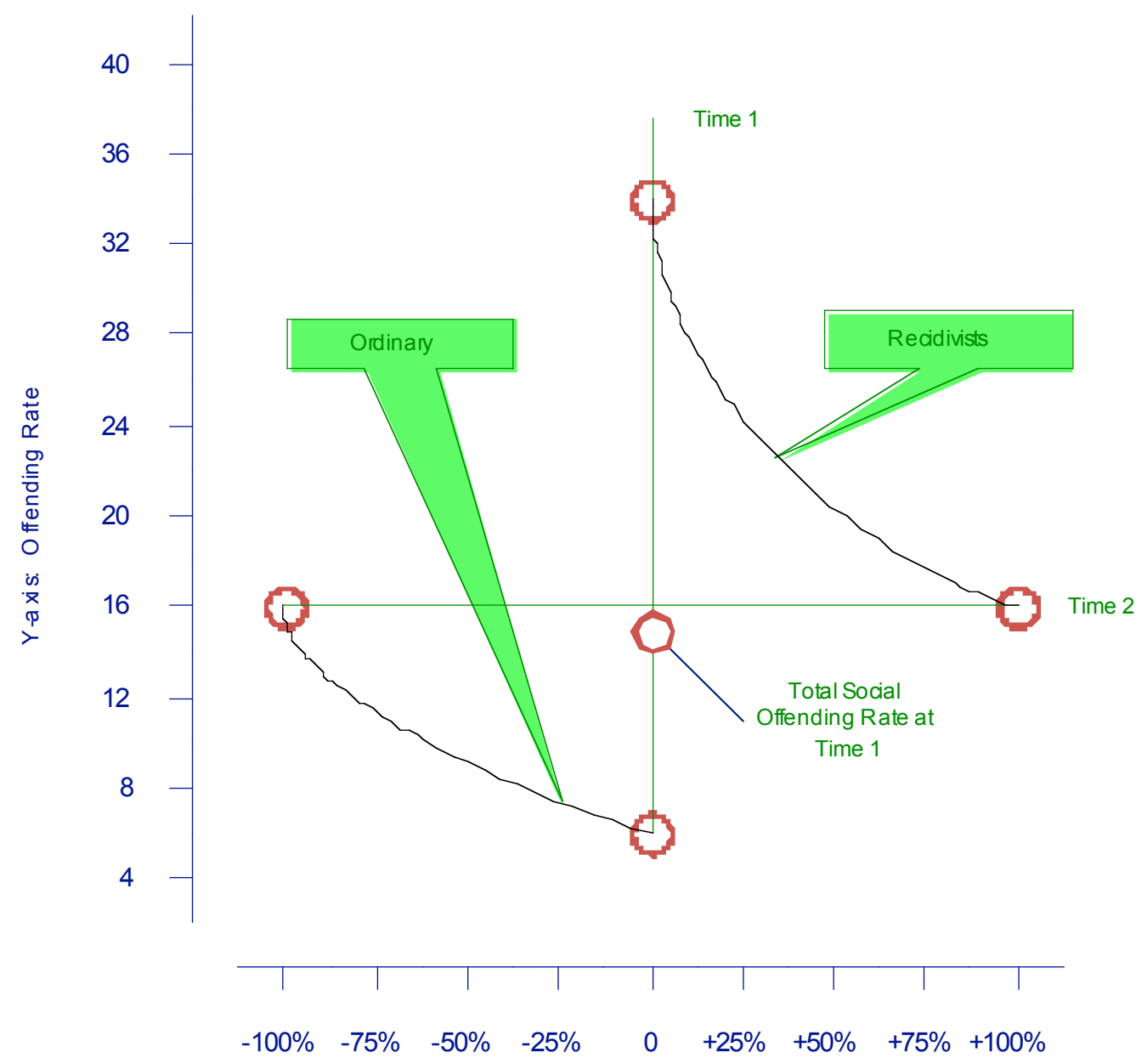

X-axis: Change in Expected Length of Sentence

As this graph demonstrates, different group elasticities can affect overall crime: if the equal offending rate at Time 2 (here 16\%) exceeds the average society-wide offending rate at Time 1 (here 15\%), parole prediction will increase overall crime. In 
case the graph is not self-explanatory, let me use simple numerical assumptions hererather than mathematical equations - to illustrate the proof.

Let's assume an adult population of 200,000,000 residents and a prison population of 2,000,000. Let's assume that about 30 million violent and property crimes are committed each year (to put this in context, in 2003, the National Crime Victimization Survey reported approximately 24 million violent and property crimes); that less than half of those offenses are reported to the police, or about 12 million (in 2003, the UCR reported about 12 million violent and property crimes); that about $20 \%$ of those - or 2.4 million offenses — are cleared by arrest (Sourcebook 2002, Table 4.19); and that about 600,000 are sent to the penitentiary per year (Reentry Trends 2003). Let's also assume that about one half of the prison population (or one million people) are "recidivists" - these persons who have offended on at least two previous occasions and will probably reoffend within the year of their release from prison (Sourcebook 2002, Table 6.42 suggests, for instance, that as many as $25 \%$ of state prisoners are returned to prison on a new prison sentence in the 3 years following release).

These recidivists are the targeted group: they have a higher likelihood of offending if released, and are the ones who will be denied parole — as soon as the parole authorities adopt a policy of targeted parole release. Let's assume that there are 60 million of them in the total population and that they account for 20 million of the crimes committed each year; under these assumptions, they would have an offending likelihood of $33.33 \%$. The rest of the population has a 10/140 likelihood of offending, or $7.14 \%$.

On these assumptions, at Time 1, total crime in society is 30 million offenses per year, for a societal offending rate on the total population of $15 \%$, composed of $33.33 \%$ for recidivists and $7.14 \%$ for ordinary citizens. At Time 2 , we select on the recidivists to impose lengthier sentences (say, by paroling ordinary offenders but not the recidivists). The idea of selecting on the recidivists, from a rational action perspective, is to make their sentences longer so that their cost of offending goes up and they offend less. As noted, the optimal length of incarceration occurs when their offending rate matches that of ordinary citizens. The net effect on total crime from shifting resources in this way, though, will depend entirely on the elasticity of the different groups. If their elasticity is such that the equality point is above $15 \%$, then there will be more crime in society as a 
whole. On this hypothetical, the total offending rate in Time 2 is now $16 \%$, resulting in higher overall crime in society. This is clear from the following two tables, which are visually represented in the above graph:

Table 1: Time 1 Assumptions

\begin{tabular}{|l|c|c|c|}
\hline & Ordinary citizens & Recidivists & Total \\
\hline Population & $140,000,000$ & $60,000,000$ & $200,000,000$ \\
\hline Prison Population & $1,000,000$ & $1,000,000$ & $2,000,000$ \\
\hline Free Population & $139,000,000$ & $59,000,000$ & $198,000,000$ \\
\hline Offending Rate & $7.14 \%$ & $33.33 \%$ & $15 \%$ average \\
\hline Annual Crimes & $9,924,600$ & $19,666,666$ & $29,591,266$ \\
\hline
\end{tabular}

Table 2: Time 2 Effects

\begin{tabular}{|l|c|c|c|}
\hline & Ordinary citizens & Recidivists & Total \\
\hline Population & $140,000,000$ & $60,000,000$ & $200,000,000$ \\
\hline Prison Population & 0 & $2,000,000$ & $2,000,000$ \\
\hline Free Population & $140,000,000$ & $58,000,000$ & $198,000,000$ \\
\hline Offending Rate & $16 \%$ & $16 \%$ & $16 \%$ average \\
\hline Annual Crimes & $22,400,000$ & $9,280,000$ & $31,680,000$ \\
\hline
\end{tabular}

The bottom line is that, at Time 2, society-wide crime has increased-compare the bottom right-hand cells. And the clincher is, we have no good idea how the elasticities compare. We presume that the different groups have different offending patterns, but we have no idea whether that also means they have different elasticity. We have no knowledge. We're in the dark. So why, you might ask, should we assume that parole prediction would be efficient in deterring crime? Why should we assume that predictions of criminality and actuarial analyses will benefit society as a whole? There is no good reason. The fact that we $d o$ believe tells us something about $u s$, more than it does about the different members of these two groups. It tells us something about our desire to believe, our desire to predict, our desire to know the recidivist. We are, it seems, predisposed to wanting the actuarial model to be right.

\section{Social Costs AND the RAtchet EFFeCT}

Not all proponents of the actuarial, however, are rational choice believers. Many endorse the turn to actuarial methods based on a more basic incapacitation rationale: if we audit 
more tax filers who are more likely to be evading taxes, we will detect and punish more tax evaders; if we stop and search more motorists who are more likely to be transporting drug contraband, we will detect and punish more drug couriers; if we deny parole to more convicts who are more likely to recidivate, we will incapacitate more hard-core offenders. Setting aside the potential adverse effect on the overall amount of crime, incapacitation theory suggests there will simply be more detection of crime-and, correlatively, fewer undetected tax evaders, fewer drug-couriers on the highways, and fewer recidivists preying on society. In short, prediction helps incapacitating more offenders with the same resources; and even more offenders with even more resources. Thus, regardless of whether it encourages or deters crime, the use of actuarial methods will likely increase the success rate of searches, audits, and parole decision, and therefore produce enhanced incapacitation of criminal offenders. This is, of course, a good thing.

Now, in addressing this incapacitation argument, it is important to distinguish between, on the one hand, the more ordinary element of incapacitation that is achieved when we shift fixed resources from incarcerating "ordinary" citizens to incarcerating "recidivists" with, on the other hand, the massive multi-billion-dollar investment we have made and are making, as a nation, in additional incapacitation during the last quarter of the twentieth century. We know from the research of Steven Levitt ${ }^{20}$ and others that the exponential increase in the prison population during the past thirty years has probably had an effect on crime. The best evidence suggests that approximately one fourth of the crime drop in America during the 1990s was in fact attributable to the prison expansion. ${ }^{21}$ In discussing the benefits of incapacitation, though, it is crucial to differentiate between this massive social investment and the more ordinary, minor incapacitation effects flowing from the mere shift in resource allocation associated with the use of actuarial methods in parole or sentencing.

With regard to the first - the massive infusion of resources associated with the exponential increase in prison populations - any analysis of the benefits of prediction must ask, first, what role prediction played in the equation, and, second, whether those massive resources could have been better spent on other crime-fighting practices, such as

\footnotetext{
${ }^{20}$ Steve Levitt's 2004 Journal of Economic Perspectives review essay.

${ }^{21}$ See William Spellman, "The Limited Importance of Prison Expansion," at page 123, in The Crime Drop in America, eds. Alfred Blumstein and Joel Wallman (Cambridge University Press 2000).
} 
increased police presence, more drug treatment programs, free abortions, mandatory military conscription, or other policies. If we as a society are willing to pour tremendous resources into fighting crime, then we have to compare the role and use of actuarial methods against the provision of free abortions or whatever else apparently reduces crime. This is a much larger and more complicated calculus.

With regard to the ordinary incapacitation effects - internal in fact to the rational choice policy - these are likely to be relatively small. In our hypothetical, for instance, they are washed out by the effect of the change in offending: there is no incapacitation effect if you imprison a recidivist versus an ordinary citizen once the rates of offending have equalized.

\section{(a) Incapacitation in Policing and Law Enforcement}

But even assuming that there are significant incapacitation gains, the question is, at what cost? Such an evaluation, naturally, calls for cost benefit analysis. The benefitsfor instance, a marginal increase in the detection of tax evaders or drug couriers- do not come without a price. As just noted, one price may be increased overall crime; and if that is true, then clearly - or at least, I believe, everyone would agree, given that the primary goal of increased detection is lower crime - the price is too expensive. The question is, what other costs are there?

Here, I would like to emphasize one particular cost that is generally overlooked in large part because it focuses on the guilty and not on the innocent. I am referring here to what I call the "ratchet effect." Under normal conditions, the use of accurate prediction instruments will have a distortive effect on the targeted population, a distortion that ultimately operates as a ratchet. The distortion occurs when successful profiling produces a supervised population that is disproportionate to the distribution of offending by racial group. To give a rapid illustration drawing on the earlier discussion of racial profiling, if minorities represent 20 percent of motorists on the road, but 30 percent of the persons carrying drug contraband on the highway, then minority motorists are offending at a higher proportion than their representation in the general motorist population. If the police achieve equal hit rates by deploying 60 percent of their searches on minority motorists, then minority motorists will represent 60 percent of the population with negative police contacts resulting in some correctional trace, whether simply an arrest or 
more serious carceral supervision. The difference between minority motorists representing 30 percent of the offenders and 60 percent of persons with a correctional trace represents a distortion that has significant negative effects on the minority population. This distortion will produce a ratchet if law enforcement then relies on the evidence of correctional traces in order to reallocate future law enforcement resources. And the fact is, given the paucity of reliable information on natural offending rates, law enforcement relies heavily on arrest, conviction, and supervision data in deciding how to allocate resources. This, in turn, accelerates the imbalance in the prison population and acts like a ratchet. How serious the distortion and ratchet effect will be depends, again, on subtle variations in comparative elasticities and offending rates. But some distortion is practically inevitable.

The reason, in essence, is that when we profile, we are essentially sampling more from a higher-offending population. Instead of sampling randomly — which would net a proportional representation of the offending population-we are sampling in greater numbers from the pool of higher offenders, and thereby skewing our sample results. Somewhat counter-intuitively, the only way to produce a prison population that mirrors the offending population is to sample randomly from the general population - to engage in essentially random searches, or random audits, or random policing. Barring that arbitrariness, our results will be distorted.

What the ratchet effect does is to disproportionately distribute criminal records and criminal justice contacts with terrible effects on the profiled population. Disproportionate criminal supervision and incarceration reduces work opportunities, breaks down families and communities, and disrupts education. It contributes to the exaggerated general perception in the public imagination and among law enforcement officers of the criminality of the targeted group. This, in turn, further undermines the ability of members of the targeted group to obtain employment or pursue educational opportunities. It may also have a delegitimizing effect on the criminal justice system that may encourage disaffected members of the profiled group to deviate further from the criminal law in a kind of backlash against perceived or real prejudice. And it may corrode community-police relations, hampering law enforcement efforts as members of the profiled community become less willing to report crime, to testify, and to convict. 
In this sense, the use of actuarial methods in the criminal justice context can affect the life-course of the individual in extremely detrimental ways. It can result in "selffulfilling effects" on employment, education, family, etc. These are the detrimental affects on African-Americans of being perceived as criminals - what Dorothy Roberts discusses under the rubric of "Black criminality.",22

(b) Sentencing Matters

The ratchet effect is most clearly evident in the context of racial profiling - or criminal profiling more generally. There, disparities between the offending population and the prison population have significant symbolic effects: the black face of the incarcerated inmate, the silk stocking of the tax evader, the blue collar of the drywall contractor, these are all powerful symbolic products of the ratchet effect. It is less obvious, though, how this ratchet critique applies to the sentencing and punishment contexts - to the slightly different use of actuarial methods to predict future criminality or recidivism in determining sentencing outcomes. But here also-again somewhat counterintuitively - the critique applies to these other forms of actuarial justice.

Let us take here, for purposes of illustration, the case of likely recidivists who are disproportionately denied parole or sentenced under enhancement statutes and, as a result, are disproportionately represented in prison. The symbolic message associated with their disproportionate representation among the correctional population-that is, with the correct perception that the prison is "filled with recidivists" - is the following: "if you offend once, you are likely to offend again; if you offend twice, it's all over." The result is a powerful symbolic message that turns convicts into even worse offenders-in the public imagination, but also in the re-entry context. This too will have self-fulfilling prophecy effects, reducing employment and education opportunities upon re-entry. In fact, there is no good reason to expect that the effect will be any different than the effect of racial profiling on "Black criminality."

There are, naturally, other costs to consider. I emphasize here the ratchet effect. But others have properly emphasized other costs. Some point to the reduced obedience to the law resulting from the perceived reduced legitimacy of the criminal justice system.

\footnotetext{
22 See Dorothy E. Roberts, Foreword: Race, Vagueness, and the Social Meaning of Order-Maintenance Policing, 89 J. Crim. L. \& Criminology 775 (1999).
} 
Psychologist Tom Tyler has demonstrated how perceptions of the legitimacy of the criminal justice system affect the willingness of citizens to abide by the law. Tyler's book Why People Obey the Law (1990), and his writings on procedural fairness and institutional legitimacy, including his essay Trust and Democratic Governance (1998), rest precisely on the idea that individuals derive a strong sense of identity from their relationship with legal authority. When the relationship is positive and respectful, a form of social trust - a concept closely linked to the idea of social capital made popular in Robert Putnam's book, Bowling Alone, as well as the notion of collective efficacy in the work of Robert Sampson-develops and promotes obedience to the law. "[S]ocial trust," Tyler contends, "is linked to creating a commitment and loyalty to the group and to group rules and institutions." 23 This commitment and loyalty to the group translates into greater obedience to the law. When this loyalty is undermined, so too is obedience to the law. My colleague, Tracey Meares, along with Chris Winship and Jeffrey Fagan, are pursuing important research with Tom Tyler in this area.

Other commentators have emphasized the link between targeted enforcementparticularly in the case of racial profiling - and increased police misconduct. So, for instance, the implementation of a targeted policing strategy focused on increased stopand-frisk searches on the streets of New York City was accompanied with disproportionate searches of African-American and Latino citizens, as well as a sharp rise in the number of civilian complaints of police misconduct, including brutality. Still others have focused on the direct costs on families and the incarcerated. ${ }^{24}$

These costs need to be weighed against the incapacitation effects. The fact is, the incapacitation argument - though incredibly powerful given our recent experiment with exponential incarceration - is typically boundless. Standing alone, it is indiscriminate. It does not tell us how much incapacitation is socially optimal. It has no internal limiting principle. Taken to its extreme, the incapacitation argument militates in favor of full incarceration of, say, the male population between the ages of 16 and 24 . That, of course, is absurd - or at least, should be absurd. But what it points to is that, ultimately, we do

\footnotetext{
${ }^{23}$ Tyler 1998:289

${ }^{24}$ The NAACP Legal Defense Fund, for instance, has done a study in Mississippi looking at the cost of pretrial detention to the community in terms of lost income of the prisoners and loss of ability to support their families.
} 
have to be willing to perform a cost-benefit analysis on crime. We have to be willing to engage in a cost-benefit analysis to determine whether the potential reduction in crime attributable to an incapacitation effect outweighs any costs associated with the increased incapacitation.

And in this cost-benefit analysis, the burden of proof and persuasion must rest on the proponents of the actuarial. If the predictor is race - as in racial profiling - then the constitutional heightened standard of strict scrutiny requires that the government should carry the burden. But, I would suggest, precisely because of the ratchet effect, the same should be true in the case of classifications based on gender, class, wealth, etc. The ratchet effect is so problematic that it warrants shifting the burden of proof and persuasion on the proponents of the actuarial. The presumption should favor randomization; the default should be color-blind or, more generally, prediction-blind. And we should only move away from this presumption if the advocates of profiling can demonstrate that the distortion and possible ratchet will not be unduly burdensome.

\section{Distorting OUR CONCEPTIONS OF Justice}

There is one other troubling dimension to the actuarial turn-one that lends itself less easily to mathematical proof, to demonstration, to equations that show how the use of prediction instruments may actually increase the social cost of crime. This last dimension maps less easily onto graphs, formulas, and tables - to visual representations of ratchet effects and other externalities. But it is no less troubling.

The actuarial turn has begun to shape our conception of just punishment. The use of predictive methods has begun to distort our carceral imagination, to mold our notions of justice, without our full acquiescence - without deliberation, almost subconsciously or subliminally. Today, we have an intuitive, but deep sense that it is just to determine punishment in large part on the basis of an actuarial risk assessment. We have come to associate the prediction of future criminality with just punishment. This seems intuitively obvious, even necessary. Who on earth would object? From a social welfare perspective, it makes all the sense in the world to try to reduce social harm and injury-and thereby decrease the cost of crime-by using prediction instruments, by identifying ahead of time the more likely offender. 
But, the fact is, we have chosen this conception of just punishment. We have chosen it from among a wide spectrum of theories of punishment. It is not natural, obvious, or necessary. We embraced it from a variety of equally attractive conceptions of justice. We chose it as against a rehabilitative model and as against a more strictly retributivist model.

Or rather, it chose us. Remarkably, what triggered the shift in our conception of just punishment from notions of reform and rehabilitation to notions of risk assessment in the late twentieth century is the production of technical knowledge: our progress in techniques of predicting criminality is what fueled our jurisprudential conception of just punishment. It is possible to trace the shift in our conception of justice-from rehabilitation in the 1960s and 70s to incapacitation in the 1980s and 90s - to the popular rise of actuarial methods and their implementation. Incapacitation as the model of punishment grew in part because it is what we began to know technically. To be sure, there were many other factors as well - factors that David Garland describes powerfully in his work, The Culture of Control. But one important factor-one factor that has received less attention - is precisely the development of technical knowledge, and, as the driving force behind it, the will to know.

The structural transformation of our conception of just punishment at the end of the twentieth century is a case of justice conforming itself to our developing technical knowledge. This is a case of philosophical and legal notions of justice following technical progress. And what is remarkable is that the impulse, the original catalyst, the stimulant in all this was exogenous to the legal system. It all came from the field of sociology and from the positivist desire to place human behavior on a more scientific level-from the desire to control human behavior, just as we control nature. The rise of the actuarial itself was born of the desire to know the criminal scientifically, and this scientific drive produced the technical knowledge that colonized our conception of just punishment.

What we have done, by and large, is to allow the actuarial to displace earlier conceptions of justice and just punishment. Today, the amount of punishment that we mete out is determined largely by the inmate's likelihood of reoffending. The criminal sentence is pegged primarily to prior criminal history and the likelihood of recidivism as measured by instruments such as the LSI-R or the Salient Factor Score or by more 
intuitive metrics such as prior history of institutionalization and drug use. (It is also, of course, pegged today to prison bed availability in the sense that shortages in capacity necessarily constrain prison populations).

If we had developed a way to measure intentionality - a thermometer for intentthere would likely be a push to punish based on moral culpability. If we had developed a way to measure deterrence, we would more likely see a push toward deterrence. If we had developed a more rigorous way to equate moral blame and punishment (through better measures of pain), there might be a renewed push toward retributivism. This is, in some sense, remarkable - and deeply troubling. It is deeply troubling because it demonstrates the influence of technical knowledge on our sense of justice. We have become, in a sense, the slaves of our technical advances.

We have come to believe that it is just for punishment to relate primarily to the statistical probability of reoffending. This breaks the link between just punishment and the heinousness of the offense, and thereby attenuates the retributive element of punishment. It also breaks the link to the deterrent effect of punishment. Conceptually, one could imagine that more punishment may be necessary to deter the convict who is likely to reoffend, but this is purely speculative. There is no direct connection to a determination of the punishment necessary to deter the commission of the crime in question. It also attenuates the link to rehabilitation and reformation, especially where the actuarial method relies on static past indices such as prior criminal record.

What is left, from the perspective of punishment theory, is incapacitation (constrained by prison-bed capacity). This represents a negative form of incapacitation: the idea is not that we should compute optimal incarceration in order to efficiently incapacitate likely future offenders; instead, the idea is that we need to kick people out of prison and we might as well send out those who are less likely to offend again. It is an incapacitation approach by default of a better system.

Utilitarian theories of deterrence fall aside because there is no good measure of deterrence. It is not yet possible to calibrate properly the quantum of punishment necessary to deter any particular individual. There is no way to mete out punishment in a scientific way along these lines. We can argue about whether there should be more punishment generally or less, but these are crude arguments indeed. Retributive theories 
also subside for lack of a good metric. Here too, there is no technical knowledge on the subject. No thermometer to measure intent. No blood test for villainy. Rehabilitation proves inadequate because it cannot be shown to be technically right.

The only technical knowledge we have developed is simple binary prediction based on objective measures. Simplistic, basic, but predictive-it can be proven right. It can be validated, tested, replicated. It is a form of technical knowledge that makes possible "right" and "wrong" answers. In the end, it is this quest for technical knowledge that has helped shape our contemporary notions of justice. This is a story of technical knowledge taming just punishment. And it is remarkable - remarkable because it flips on its head the traditional relationship between social science and the legal norm.

This is true as well in the policing context more generally. What happens is that we begin to feel justified about punishing the members of the targeted group because they offend at higher rates. We begin to feel that they are legitimate targets of punishment not because of their offending activity, but because of the characteristic trait that we profile. Take, for example, the case of profiling the rich for IRS audits or minorities for drug searches. At some point, the lines begin to blur and we begin to feel morally righteous about going after the rich for tax evasion or minorities for drug trafficking because we begin to associate the profiled trait with suspicion. Not everyone, of course, does this. But there is a tendency. It begins to alleviate our scruples, even if slightly. We are just a little bit less disturbed - even though we may be creating huge disparities in the prison or correctional contexts. We become a little bit less troubled by the collateral consequences, precisely because we begin to perceive these groups as more criminal.

\section{SHADES OF GRAY}

What about situations where the criminal justice outcome turns exclusively on a quantity of interest that needs to be predicted? Let's take, for example, the bail determination: the decision whether to grant bail depends precisely on a prediction whether the accused is likely to flee the jurisdiction to avoid trial. The embedded criminal justice standard is all about prediction. And in fact, in the 1960's, the Vera Institute developed risk assessment criteria for pretrial release decisions that were extremely beneficial to poor and disadvantaged defendants. The use of actuarial methods led to the greater reliance on 
recognizance bonds and less reliance on money bail. How should we evaluate the use of actuarial methods in this type of situation?

The fact that the Vera Institute's risk assessment criteria benefited the poor and minorities cannot be the determinative factor. There cannot be a political or ideological litmus test to these arguments against the actuarial. The IRS Discriminant Index Function, after all, may also benefit the less wealthy and yet it is equally problematic as a form of criminal profiling. And the arguments against the actuarial apply to predicting future dangerousness but also to predicting future rehabilitation - the flip side of recidivism. The arguments, in this sense, do not have a necessary political valence.

The case of bail determinations is problematic, then, precisely for this reason: in the case of bail, the standard embedded in the criminal justice determination - risk of flight - maps onto prediction perfectly. In the bail context, the criminal justice outcome is precisely the prediction of future behavior-skipping bail and fleeing the jurisdiction. Notice that this is not the case with the other examples: criminal profiling aims at reducing crime; parole prediction and selective incapacitation aim at imposing just punishment. In all the previous cases, prediction of future behavior is being substituted for a larger criminal justice end. In the bail example, though, the goal itself is to predict who is a risk of flight pretrial. The bail determination is specifically about prediction. It does not use prediction as a means toward some other end (fighting crime or just punishment), it is all about prediction. In this context, we tend to think: "The more accurate the prediction, the better. What is the big deal with having a jail that is chock full of people who would likely flee the jurisdiction? That's the whole point of detaining them!"

With this bail example, the first, mathematical critique may apply perfectly well. If there are different elasticities as between low risk and high risk pretrial detainees, then profiling heavily may in fact shift the fleeing rates of low-risk detainees more and, as a result, increase the total number of defendants who flee the jurisdiction pretrial. But the ratchet effect does not seem to present a problem. The question here, then, is whether the second, ratchet-effect critique extends to categories that either map on directly to the criminal justice outcome or are in some sense less important or troubling than race, gender, or class. 
The answer is that all profiling runs along a spectrum where, at one end, there is the criminal activity itself, narrowly defined, and at the other end, there are the broadest categories of race, gender, religion, class, wealth, and other identifiers. The closer the particular prediction is to the criminal act itself, the more comfortable we tend to be with the use of prediction. Profiling people who are running down the street with a TV in a shopping cart or who have a bicycle without a seat and front wheel, is less troubling to us than using race or gender as a proxy for suspicion. Profiling people who are likely to jump bail seems less troubling as well. Here we are no longer profiling to achieve some other end, we are really addressing the problem at hand. On the other hand, the closer the particular prediction is to the broad categories of race, gender, religion or class, the more uncomfortable we are with the predictive method. Profiling African-Americans, men, Muslims, or the rich is more troubling to us.

It is important to recognize this spectrum and acknowledge that the force of the three arguments presented in this article applies with more strength at one end of that spectrum - where predictions are based on the broad categories (race, gender, wealth). These categories are more distant and unrelated to the ultimate criminal justice objective, for instance catching the criminal or denying bail to the fugitive. Nevertheless, while acknowledging the different force of the arguments, I would argue that there are still problems with practically all forms of profiling. These problems come in two forms.

First, even when we are using prediction with regard to a criminal justice outcome that calls for prediction, we are likely to stigmatize other categories. So for instance, in the case of bail, using a risk assessment tool will likely produce an outcome that signifies that "drifters" are dangerous people who need to be detained. Drifters are more likely to flee the jurisdiction. The troubling consequence is that the profiling may lead to social conformity. Profiling even where it seems most necessary may have the effect of marginalizing anyone who deviates from the norm and thereby may impose pressure on them to conform.

Second, even when we use an innocuous trait - a category that does not bother us as much as race, gender or class - we are still derivatively, rather than directly, creating stigma. Take for example the category of "speeders"- people who habitually drive over the speed limit, and assume for a moment that there is a correlation with drug trafficking. 
Barring racial profiling, state troopers may decide to seek consent to search cars driven by all persons who speed. If the troopers do indeed target speeders, this will likely produce a ratchet along the lines of speeders and non-speeders. It will produce a disproportionate correctional population that will likely communicate that "speeders" are, for instance, affiliated with the drug trade.

Some will rightly respond: "But that's what we want, right? To eliminate speeding, for instance?" And my response is that, here too, as in the case of just punishment theory, we should make independent judgments about the penal lawindependent of the effects of prediction. We may indeed want to criminalize speeding. But if so, it should be a decision about speeding, and not the product of a desire to criminalize drug trafficking. Not because speeding predicts drug trafficking. We need to reach the decision independently. We should not allow our actuarial methods to reshape or distort our law enforcement decisions.

In practically all of these cases, there is a solution that avoids using prediction. There is a way to come up with a non-predictive, independent measure that satisfies the criminal justice goal. In the bail context, for instance, magistrates could determine bail based on the gravity of the offense charged. The categories that would determine bail, then, would be the classification of felonies and misdemeanors. If magistrates are concerned about wealthy defendants skipping town because the amount set is too low, then the gravity-of-offense scale can be pegged to annual salary or total assets. In the case of prison classification - another example of a classification where the prediction of future dangerousness seems so central to the criminal justice determination-prison authorities could also use the seriousness of the crime for which the person has been convicted: persons guilty of first-degree murder would get one form of custody - say, the equivalent of our maximum security facilities - and persons convicted of grand auto theft would get a different form of custody - say, minimum security custody. It is practically always possible to find an independent metric that satisfies the purpose of the classification. In these two examples, the proposed alternatives relate to the crime charged, and as a result, the stigma goes only to the crime-not derivatively to some other category, such as the drifter or the speeder. 


\section{CONCLUSION}

Instead of using actuarial methods to guide criminal justice outcomes, we would be better off returning to the core insight of criminal justice, to our most central intuition of just punishment: the idea that any person committing a criminal offense should have the same probability of being apprehended as similarly situated offenders. The only way to achieve this goal, surprisingly, is to engage in more random law enforcement. "Randomness," it turns out, is the only way to achieve a carceral population that reflects the offending population. Randomness in this context is a form of "sampling": random sampling on the highway, for instance, is the only way that the police would obtain an accurate reflection of the offending population. And this - random sampling - is the central intuition behind randomness. What randomness achieves, in essence, is to neutralize the perverse effects of prediction, both in terms of the possible effects on societal crime and of the other social costs.

Randomness translates into different practices in the policing and sentencing contexts. In the policing context, randomness is relatively straightforward: the IRS could assign a number to each tax return and audit on a lottery basis - or, for that matter, randomly select based on social security numbers. At the airport, the security details could search all passengers or employ a randomized program to select passengers to search. On the highway, the state patrol could deploy random numerical ordering to seek consent to search cars. In fact, one radical idea would be to draw social security numbers by lottery and then have a full investigation of the persons' life - audit their taxes, take a hair and urine sample for drugs, clock their driving habits, determine whether they pay social security taxes on their housekeeper, etc. This would represent the ultimate random criminal check - an interesting experiment in randomness.

In the sentencing area, randomness means something quite different. Randomness does not mean drawing names out of a hat in deciding who to parole or how long to sentence. It means eliminating the effect of predictions of future dangerousness. So we impose a sentence based, for instance, on the harm associated with the offense, or proportionally to the degree of the conviction, and then we stick by it. We neither enhance nor decrease the punishment based on predictions of future dangerousness. We do not allow prediction to infect the decision-making process. Similarly, the prison 
authorities would classify inmates for security purposes according to the degree of the felony conviction. This would neutralize the perverse effects of prediction in the sentencing context.

Nothing in my argument suggests that we, as a society, should stop researching and theorizing prediction instruments. It is not even clear that we could. It is difficult to imagine quenching our thirst for technical knowledge in the human sciences-especially because of the astounding accomplishments we have achieved in the natural sciences. Human progress in communication, transportation, and medicine are models of success, and the advances we have made in those areas are simply astounding. From the first flight to the first steps on the moon, from the telegraph to wireless internet connections, from vaccines to the atomic bomb, our technical discoveries have led to awe inspiring heights. And yet, the human sciences - the study of our political, social, and economic organization - though dazzling at times, have not produced such awe inspiring results. Certainly, they have not helped avoid massive human suffering-whether measured in terms of world wars, genocide, hunger or malnutrition. Is it that we have not yet built the right model? Have we not yet discovered the correct variable? Have we not yet designed the right test? Possibly. Or perhaps it has something to do with the difference, ultimately, between the natural and the human. Whatever the difference, it should be possible, at the very least, to quell the desire to put these prediction instruments into practice. It should be possible to resist implementation-particularly since we are implementing them in the most devastating area of social life, in the field of crime and punishment. 
Readers with comments may address them to:

Professor Bernard Harcourt

University of Chicago Law School

1111 East 60th Street

Chicago, IL 60637 harcourt@uchicago.edu 


\section{The University of Chicago Law School Public Law and Legal Theory Working Paper Series}

1. Cass R. Sunstein and Edna Ullmann-Margalit, Second-Order Decisions (November 1999; Ethics, v.110, no. 1)

2. Joseph Isenbergh, Impeachment and Presidential Immunity from Judicial Process (November 1999; forthcoming Yale Law and Policy Review v.18 \#1).

3. Cass R. Sunstein, Is the Clean Air Act Unconstitutional? (August 1999; Michigan Law Review \#3).

4. Elizabeth Garrett, The Law and Economics of "Informed Voter" Ballot Notations (November 1999, University of Virginia Law Review, v. 85).

5. David A. Strauss, Do Constitutional Amendments Matter? (November 1999)

6. Cass R. Sunstein, Standing for Animals (November 1999)

7. Cass R. Sunstein, Culture and Government Money: A Guide for the Perplexed (April 2000).

8. Emily Buss, Without Peers? The Blind Spot in the Debate over How to Allocate Educational Control between Parent and State (April 2000).

9. David A. Strauss, Common Law, Common Ground, and Jefferson's Principle (June 2000).

10. Curtis A. Bradley and Jack L. Goldsmith, Treaties, Human Rights, and Conditional Consent (May 2000; Pennsylvania Law Review v. 149).

11. Mary Ann Case, Lessons for the Future of Affirmative Action from the Past of the Religion Clauses? (May 2001, Supreme Court Review, 2000)

12. Cass R. Sunstein, Social and Economic Rights? Lessons from South Africa (May, 2000).

13. Jill Elaine Hasday, Parenthood Divided: A Legal History of the Bifurcated Law of Parental Relations (June 2001)

14. Elizabeth Garrett, Institutional Lessons from the 2000 Presidential Election (May 2001).

15. Richard A. Epstein, The Allocation of the Commons: Parking and Stopping on the Commons (August 2001).

16. Jack Goldsmith, The Internet and the Legitimacy of Remote Cross-Border Searches (October 2001).

17. Adrian Vermeule, Does Commerce Clause Review Have Perverse Effects? (October 2001).

18. Cass R. Sunstein, Of Artificial Intelligence and Legal Reasoning (November 2001).

19. Elizabeth Garrett, The Future of Campaign Finance Reform Laws in the Courts and in Congress, The William J. Brennan Lecture in Constitutional Law (December 2001).

20. Julie Roin, Taxation without Coordination (March 2002).

21. Geoffrey R. Stone, Above the Law: Research Methods, Ethics, and the Law of Privilege (March 2002; forthcoming J. Sociological Methodology 2002).

22. Cass R. Sunstein, Is There a Constitutional Right to Clone? (March 2002).

23. Emily Buss, Parental Rights (May 2002, forthcoming Virginia Law Review).

24. David A. Strauss, Must Like Cases Be Treated Alike? (May 2002).

25. David A. Strauss, The Common Law Genius of the Warren Court (May 2002).

26. Jack Goldsmith and Ryan Goodman, U.S. Civil Litigation and International Terrorism (June 2002).

27. Jack Goldsmith and Cass R. Sunstein, Military Tribunals and Legal Culture: What a Difference Sixty Years Makes (June 2002).

28. Cass R. Sunstein and Adrian Vermeule, Interpretation and Institutions (July 2002).

29. Elizabeth Garrett, Is the Party Over? The Court and the Political Process (August 2002).

30. Cass R. Sunstein, The Rights of Animals: A Very Short Primer (August 2002). 
31. Joseph Isenbergh, Activists Vote Twice (November 2002).

32. Julie Roin, Truth in Government: Beyond the Tax Expenditure Budget (November 2002).

33. Cass R. Sunstein, Hazardous Heuristics (November 2002).

34. Cass R. Sunstein, Conformity and Dissent (November 2002).

35. Jill Elaine Hasday, The Principle and Practice of Women's "Full Citizenship": A Case Study of Sex-Segregated Public Education (December 2002).

36. Cass R. Sunstein, Why Does the American Constitution Lack Social and Economic Guarantees? (January 2003).

37. Adrian Vermeule, Mead in the Trenches (January 2003).

38. Cass R. Sunstein, Beyond the Precautionary Principle (January 2003).

39. Adrian Vermeule, The Constitutional Law of Congressional Procedure (February 2003).

40. Eric A. Posner and Adrian Vermeule, Transitional Justice as Ordinary Justice (March 2003).

41. Emily Buss, Children's Associational Rights? Why Less Is More (March 2003)

42. Emily Buss, The Speech Enhancing Effect of Internet Regulation (March 2003)

43. Cass R. Sunstein and Richard H. Thaler, Libertarian Paternalism Is Not an Oxymoron (May 2003)

44. Elizabeth Garrett, Legislating Chevron (April 2003)

45. Eric A. Posner, Transfer Regulations and Cost-Effectiveness Analysis (April 2003)

46. Mary Ann Case, Developing a Taste for Not Being Discriminated Against (May 2003)

47. Saul Levmore and Kyle Logue, Insuring against Terrorism — and Crime (June 2003)

48. Eric Posner and Adrian Vermeule, Accommodating Emergencies (September 2003)

49. Adrian Vermeule, The Judiciary Is a They, Not an It: Two Fallacies of Interpretive Theory (September 2003)

50. Cass R. Sunstein, Ideological Voting on Federal Courts of Appeals: A Preliminary Investigation (September 2003)

51. Bernard E. Harcourt, Rethinking Racial Profiling: A Critique of the Economics, Civil Liberties, and Constitutional Literature, and of Criminal Profiling More Generally (November 2003)

52. Jenia Iontcheva, Nationalizing International Criminal Law: The International Criminal Court As a Roving Mixed Court (January 2004)

53. Lior Jacob Strahilevitz, The Right to Destroy (January 2004)

54. Adrian Vermeule, Submajority Rules (in Legislatures and Elsewhere) (January 2004)

55. Jide Nzelibe, The Credibility Imperative: The Political Dynamics of Retaliation in the World Trade Organization's Dispute Resolution Mechanism (January 2004)

56. Catharine A. MacKinnon, Directions in Sexual Harrassment Law: Afterword (January 2004)

57. Cass R. Sunstein, Black on Brown (February 2004)

58. Elizabeth F. Emens, Monogamy's Law: Compulsory Monogamy and Polyamorous Existence (February 2004)

59. Bernard E. Harcourt, You Are Entering a Gay- and Lesbian-Free Zone: On the Radical Dissents of Justice Scalia and Other (Post-) Queers (February 2004)

60. Adrian Vermeule, Selection Effects in Constitutional Law (March 2004)

61. Derek Jinks and David Sloss, Is the President Bound by the Geneva Conventions? (July 2004)

62. Derek Jinks and Ryan Goodman, How to Influence States: Socialization and International Human Rights Law (March 2004)

63. Eric A. Posner and Alan O. Sykes, Optimal War and Jus Ad Bellum (April 2004)

64. Derek Jinks, Protective Parity and the Law of War (April 2004)

65. Derek Jinks, The Declining Significance of POW Status (April 2004) 
66. Bernard E. Harcourt, Unconstitutional Police Searches and Collective Responsibility (June 2004)

67. Bernard E. Harcourt, On Gun Registration, the NRA, Adolf Hitler, and Nazi Gun Laws: Exploding the Gun Culture Wars \{A Call to Historians\} (June 2004)

68. Jide Nzelibe, The Uniqueness of Foreign Affairs (July 2004)

69. Derek Jinks, Disaggregating "War" (July 2004)

70. Jill Elaine Hasday, Mitigation and the Americans with Disabilites Act (August 2004)

71. Eric A. Posner and Cass R. Sunstein, Dollars and Death (August 2004)

72. Cass R. Sunstein, Group Judgments: Deliberation, Statistical Means, and Information Markets (August 2004)

73. Adrian Vermeule, Constitutional Amendments and the Constitutional Common Law (September 2004)

74. Elizabeth Emens, The Sympathetic Discriminator: Mental Illness and the ADA (September 2004)

75. Adrian Vermeule, Three Strategies of Interpretation (October 2004)

76. Cass R. Sunstein, The Right to Marry (October 2004)

77. Jill Elaine Hasday, The Canon of Family Law (October 2004)

78. Adam M. Samaha, Litigant Sensitivity in First Amendment Law (November 2004)

79. Lior Jacob Strahilevitz, A Social Networks Theory of Privacy (December 2004)

80. Cass R. Sunstein, Minimalism at War (December 2004)

81. Eric A. Posner, The Decline of the International Court of Justice (December 2004)

82. Tim Wu, The Breach Theory of Treaty Enforcement (February 2005, revised March 2005)

83. Adrian Vermeule, Libertarian Panics (February 2005)

84. Eric A. Posner and Adrian Vermeule, Should Coercive Interrogation Be Legal? (March 2005)

85. Cass R. Sunstein and Adrian Vermeule, Is Captial Punishment Morally Required? The Relevance of Life-Life Tradeoffs (March 2005)

86. Adam B. Cox, Partisan Gerrymandering and Disaggregated Redistricting (April 2005)

87. Eric A. Posner, Political Trials in Domestic and International Law (April 2005)

88. Cass R. Sunstein, Irreversible and Catastrophic (April 2005)

89. Adam B. Cox, Partisan Fairness and Redistricting Politics (April 2005, NYU L. Rev. 70, \#3)

90. Cass R. Sunstein, Administrative Law Goes to War (May 2005, Harvard L. Rev., forthcoming)

91. Cass R. Sunstein, Chevron Step Zero (May 2005)

92. Bernard E. Harcourt, Policitng L.A.'s Skid Row: Crime and Real Estate Development in Downtown Los Angeles [An Experiment in Real Time] (May 2005)

93. Bernard E. Harcourt and Jens Ludwig, Broken Windows: New Evidence from New York City and a Five-City Social Experiment (May 2005)

94. Bernard E. Harcourt, Against Prediction: Sentencing, Policing, and Punishing in an Actuarial Age (May 2005) 